\title{
Germany seeks limited European projects...
}

Munich. Germany is expected to propose that, for the first time, some specific research projects funded under the European Commission's next four-year Framework programme, which starts in 1998, should be restricted to a limited number of member states. position paper that the German government is due to publish later this month in response to the commission's request for formal input from member states before it puts forward its own proposal for the next Framework programme by the end of the year.

Like those of Britain, the German suggestions emphasize the need to improve efficiency while controlling application numbers. For example, it would like to see the management of some programmes delegated to organizations with appropriate expertise within the member states.

This has already been tried out with a plant biotechnology project called AMICA, which has been handled by the John Innes Research Institute in the United Kingdom. But the commission has been reluctant to
The proposal is likely to be included in a

European governments last week pre sented to the European Commission in Brussels their recommendations for the Fifth Framework programme, its four-year, ECU12.3-billion (US\$15.1. billion) programme of joint research, which is due to commence in 1998. We report here proposals from Germany, France and Britain. Submissions from other countries, as well as from bodies such as the European Science Foundation, will be covered in future weeks. The commission's final proposals are due by the end of the year.

experiment further with this idea because it is not clear that it has a legal right to do so.

In erder to limit the number of applications, Germany would like to introduce a concept of 'variable geometry', under which participation in certain programmes would be restricted to a few identified countries with appropriate research strengths, rather than all 15 member states.

One such programme might be in aero-

\section{... as France backs competitiveness}

London. France has claimed that the costs of running the Framework Programme are "too expensive", and has suggested that "bold and imaginative" solutions are needed to remedy a situation that "could challenge the very existence of such an investment by the European Union".

It has also proposed, in common with its main European partners, that the main thrust of the Fifth Framework programme should be more clearly focused on increasing the competitiveness of industry.

At the same time, it says there should be a specific programme of basic research linked closely to technology-based programmes, based on concern that an excessively utilitarian approach could undermine the long-term investments needed to maintain 'upstream' research.

France would also like to see a programme to support 'technological leaps', organized through what it calls a 'bottomup' procedure, allowing new sectors to be covered and assuring flexibility and adaptability in the programme.

These and other proposals were put forward last week by François d'Aubert, the secretary of state for research, following consultation with industry, government and academic groups in France.

Speaking in Paris at a meeting held to discuss the results of this consultation exercise, d'Aubert said that analysis of the responses had revealed a "remarkable convergence" in the comments received, and also that informal contacts with
British and German officials "tie in with the main thrust of our analysis".

According to d'Aubert, the current Framework programme suffers from two structural defects, both of which require correction. The first is that it spends too much money on achieving the European Union (EU)'s goal of "cohesion" supporting research of limited strategic value in "less competitive" member states.

A second defect is the slowness and cost of administering the programme, including the costs incurred by applicants which, given the low success rates in some programmes, could, in aggregate, exceed the value of the grants. David Dickson

\section{.... and Britain pursues key role for 'users'}

Munich. Britain has proposed that the joint research efforts of the European Union (EU) should be remodelled along similar lines to those on which its own science and technology policies have been based since the publication of its domestic white paper (policy document) on science and technology in May 1993.

In particular, Britain says that a far greater role should be given to the 'user community', primarily the industrial sector but also government departments and other public institutions, in setting the research agenda for the Fifth Framework programme, which starts in 1998, to ensure that the programme's output is "genuinely responsive to Europe's needs". been chosen. one to five per cent. nautics. This position has the support of at least the Netherlands, and there is provision for such a concept within the Maastricht Treaty. But countries likely to be excluded are unlikely to be enthusiastic.

The German paper points to the need for mechanisms to recognize and correct problems as they arise during the running of the programme. It also argues that, in defining research objectives, more use should be made of technology foresight programmes.

At the same time, Germany would like the number of programmes to be reduced considerably, both to reduce the number of applications and to concentrate funds. It suggests seven: informatics, production processes and material sciences, environmental and marine sciences, life sciences, energy, transport and mobility, and socioeconomic research.

Germany specifies themes that it believes should cut across its suggested programmes. These are ageing, robotics, vaccines and viral diseases, clean power stations, telemedicine, and the car of the future - subjects of existing or possible future task forces.

It strongly supports the expansion of the task force concept introduced last year by the research commissioner, Edith Cresson, as a means of coordinating research on specific topics across programmes and across commissions.

It also supports the move by the commission to use proposed additional funds promised to the Fourth Framework programme, which have yet to be approved by the Council of Ministers, to test the effectiveness of at least some of Cresson's task forces. But it criticizes the 'top-down' process by which task forces have so far

Germany is particularly keen for the increased development of research programmes geared to cooperation with countries of Central and Eastern Europe

Alison Abbott

In a position statement published in London last week, the UK government also recommends a large increase in funding for activities relating to the dissemination and exploitation of research results, increasing their share of the Framework budget from

Other suggestions are increased efforts to monitor and evaluate research projects, improvements to the grant application procedure - including "clearer, more consistent and more timely publicity and advice to applicants" - and contracting out some aspects of contract management.

But, not surprisingly in view of its history, Britain opposes any increase in the programme's budget; it says that the over- 